\title{
Alice Munro's Who Do You Think You Are? as Cultural Moment: Colonial Culture Turned Inside Out
}

\section{Christine Lorre-Johnston}

\section{(2) OpenEdition \\ 1 Journals}

Electronic version

URL: https://journals.openedition.org/ces/5243

DOI: $10.4000 /$ ces.5243

ISSN: 2534-6695

Publisher

SEPC (Société d'études des pays du Commonwealth)

\section{Printed version}

Date of publication: 1 April 2014

Number of pages: 103-112

ISSN: 2270-0633

\section{Electronic reference}

Christine Lorre-Johnston, "Alice Munro's Who Do You Think You Are? as Cultural Moment: Colonial Culture Turned Inside Out", Commonwealth Essays and Studies [Online], 36.2 | 2014, Online since 15 April 2021, connection on 19 July 2021. URL: http://journals.openedition.org/ces/5243 ; DOI: https:// doi.org/10.4000/ces.5243

\section{cc) (†)}

Commonwealth Essays and Studies is licensed under a Licence Creative Commons Attribution - Pas d'Utilisation Commerciale - Pas de Modification 4.0 International. 


\section{Alice Munro's Who Do You Think You Are? \\ as Cultural Moment: \\ Colonial Culture Turned Inside Out}

Who Do You Think You Are? is inscribed in a cultural and literary context where the colonial heritage uncomfortably straddles two major cultural moments: modernism in the 1950s, and, in the 1960s and 70s, the counter-culture that originated in the United States. Considering "The Beggar Maid" and "Mischief" as pivotal sections of the narrative, this article will examine how this double cultural encounter is a source of confusion and irony for Rose, the central character. This is reflected in the way a number of iconic cultural objects are perceived, and turned inside out.

inside out: with the inner surface turned out; turn inside out: turn the inner side outwards; colloq. cause confusion or a mess in. (Shorter Oxford English Dictionary)

Who Do You Think You Are? (1978), Alice Munro's fourth collection of short stories, makes up a cycle, as Rose is followed through key episodes of her life in the ten connected stories. Although the stories can be read individually, they acquire a different dynamic and function from the fact that they are linked and make up a consistent narrative. ${ }^{1}$ In the overall structure of the cycle, "The Beggar Maid" and "Mischief" are both central to the sequence and longer than the other stories. ${ }^{2}$ They can also be seen as the core of the collection in the sense that aesthetic and cultural questions are treated more openly in these stories, particularly the clash between colonial culture and modernism in the title story, and the effect of the U.S. counterculture, in its various forms, in "Mischief." 3 Over the course of the cycle, the reader follows Rose, an artistically inclined child who eventually becomes an actress, from girlhood into middle age, from the Depression of her childhood into the cultural and sexual Revolution of the 1960s and 1970 s, and her personal as well as aesthetic identity is subject to those times of change, as the 20th century brings forth its profound transformations. Rose observes and experiences the impact of modern times on Canadian aesthetics and culture in general; she witnesses first-hand the sort of cultural resistance, shifts, and redefinitions this process entails, with an overall move from a Victorian culture inherited in colonial times to a

1. Eight of the stories were published in magazines before being collected and published in Canada in 1978 under the title Who Do You Think You Are? The particular form of the short story cycle partly reflects various pressures put on Munro to produce a novel rather than individual stories. See McCaig (chapter 4), Lynch, Hoy and Struthers. Who Do You Think You Are? was published in 1979 by Knopf in the United States under the title The Beggar Maid: Stories of Rose and Flo, as well as in Britain. The change of title reflects the influence of Munro's agent and publishers who "felt the colloquial put-down was not familiar to Americans" (Struthers 29; see also McCaig 75-7 and Lynch n3, 215). After the publication of Who, Munro kept to the short story form (although "Chance," "Soon" and "Silence," in Runaway, form a trilogy - sometimes called the "Juliet stories" - with a sequential and narrative dynamic of its own).

2. They are respectively the fifth and sixth stories out of ten, and are both more than 40 pages long, while the other stories total between 13 and 27 pages each.

3. Walter Martin has a different reading of the overarching structure, which he divides into the beginning (the first four, which are set in Ontario), the middle (the next four, when Rose is absent from home), and the end (the last two, when she returns to West Hanratty). He also considers the central stories, set outside Ontario, as less successful than the first and last ones (Martin 98-9). 
modern, and then postmodern one. This process is perceptible in the intertextual references that are made to various emblematic works of art, both from popular and high culture, which the characters relate and respond to, and the meaning and value of which may be turned inside out.

\section{Culture, High and Popular}

Rose's experience of the social and cultural changes in her lifetime is seen from a broad perspective, and culture is to be understood in an all-encompassing sense, comprising the general development of the national culture as a collective experience, a people's ways of life (Rose's childhood during the Depression, by contrast with Patrick's family's upper-class lifestyle for instance) as well as artistic works, including literature (the reference to Macbeth in "Half a Grapefruit") and paintings (the titular "Beggar Maid" by Edward Burne-Jones). These various understandings of the term have been formulated by Raymond Williams who identifies three main meanings of the word culture in the modern sense: a "general process of intellectual, spiritual and aesthetic development"; "a particular way of life"; "the works and practices of intellectual and especially artistic activity" ("Culture" 90). The narrative problematises the relations between the various meanings of the word by pointing out the discrepancies between artistic culture and lifestyle, with a recurrent insistence, on Rose's behalf, on the fact that artistic representation does not match reality. ${ }^{4}$ Raymond Williams also looks closely at this central question of the relation between "material" and "symbolic" culture ("Culture" 91): by including material culture and the anthropological aspect of it in the understanding of culture, there is an insistence on the material production of culture, which the focus on symbolic culture tends to stand in opposition to, or to exclude. Another important aspect of the relation between artistic and material cultures is that artistic culture is associated with class distinction: its defenders have claims to superior knowledge and refinement, in connection with the notion of civility traditionally associated with the term ("Culture" 92, 88).

The social dimension of culture is fully exposed in the encounter between Rose and Patrick at university and the difference in their lifestyles. Rose's background is humble, her family is uneducated, and education for her is the way out of Hanratty and of poverty. Patrick comes from a wealthy family that has social claims. He has chosen to study history against the will of his father, a businessman, as part of a "brief rebellion against his family" (129), and he rejoices that Rose is poor, as this enables him to identify with a certain chivalrous code in which he is king: "King Cophetua and the Beggar Maid. You know. The painting. Don't you know the painting?" (93) Patrick is a caricature of middle-class pretensions and there are many symbols of that in the narrative. The pair of Wedgwood vases he is so attached to is a perfect example.

Rose describes the living room in the house where she lives with Patrick, as she is preparing to join Clifford for an illicit amorous encounter:

On the mantel were two Wedgwood vases, white with a circlet of green leaves. Patrick was very fond of these vases. Sometimes when he came home from work he went

4. Gerald Noonan speaks of Rose's (and through her, Munro's) “distrust of the illusion of art” (141), her admission to "the puzzling conflict of art and life" (142) and her "emphasis upon the narrator as a manipulator of fact and inventor of fictions" (143); Lawrence Mathews comments on Munro's "art of disarrangement" and "its continual commentary on its own tentativeness" (193). 
straight into the living room and shifted them around a bit on the mantel, thinking their symmetrical position had been disturbed. (142)

Pottery, along with other artefacts, often stands for cultural refinement and social status in Canadian fiction. In Margaret Laurence's A Bird in the House, the house of Vanessa's grandparents has valuable objects that signal her grandfather's professional success, and even during the Depression, when the family has reduced means, her grandmother remains attached to these objects and social rituals that are marks of her past status. In "To Set Our House in Order," Vanessa is told to be careful not to stain the Chinese carpet, and is told off for nearly knocking off the Dresde shepherdess on the mantelpiece (47). The tension over these objects serves to represent a certain strain due to the coexistence of different lifestyles, eras, generations, and social values. The Wedgwood vases play a similar part in $W$ ho, but are also the trigger of an irony that Rose both initiates and feels uncomfortable about. Even though at some point she liked her life with Patrick and the house they established together, she feels ambivalent about it. When she shows Jocelyn into the living room she announces: "The department store heir's dream of elegance" (142). Rose is uneasy with the bourgeois life she has chosen for herself by marrying Patrick, and dreams of a more artistic, Bohemian life, like the one Jocelyn and Clifford have. But she also feels queasy about her treachery towards Patrick. Through her mockery she rejects what his tastes stand for: his attachment to a colonial culture based on a hierarchised society that follows the English model. The irony about the Wedgwood vases lies in the fact that what Patrick takes for a symbol of taste and refinement is in fact a product of consumer society, comparable, in contemporary times, to the household appliances that Jocelyn eventually celebrates self-mockingly: "We despised people who had color television. And you know something-color television is great! [...] We're consumers! And it's Okay!" (162).

To some historians, it was during the 18th century that the idea of a consumer culture emerged in England. This was also the period during which Josiah Wedgwood founded his pottery factory and other entrepreneurs established manufactures conceived for mass production (Briggs 15). The development of Parian ware, "a hard-paste fine white unglazed porcelain resembling Parian marble" (Shorter Oxford English Dictionary), from the Greek island of Paros, represented for the manufacturers of the time a valuable medium for statuary porcelain and the possibility of "the multiplication of works of a high order of art, at a price which [rendered] them generally available” (Briggs 151). Unlike France, whose government mainly supported luxury industries, England's expanding industry, during the Industrial Revolution, aimed at catering for a mass market in textiles, stockings, and hardware. Standardised products like Wedgwood's pottery began to supply a growing home market before they were exported. As a result of the commercial revolution and the expansion of colonial markets for English manufacturers, new industries were stimulated, and the production of manufactured goods was cheapened, diversified, and expanded. The whole dialectic between home and imperial markets was thus crucial to the Industrial Revolution (Hill 246-8). This colonial circulation of goods, and the consequences it had on culture in colonies such as Canada and on the colonists' lives, is vividly evoked by Jane Urquhart in A Map of Glass when Sylvia imagines the "absurd list of all the goods Gilderson had trafficked up and down the lakes [...]: barley, cabbages, weather vanes, sets of china, hacksaws, buggies, furniture, whisky, horses, human beings" (2005: 264). In Who, the Wedgwood vases underline Patrick's ironical 
position in this colonial flow of things: mockingly presented as "the heir to a mercantile empire" by Dr. Henshawe, Patrick is also at the receiving end of the mercantile colonial system, the buyer, or inheritor of Wedgwood vases mass-produced in England that he takes for the epitome of good taste and order, in their perfect symmetry. The vases are also associated with a sense of History, both because of their neo-classical style, inspired at a time when Britain was developing its empire, and because they often represented royalty or other historical characters.

Architecture in several instances conveys similar distant associations with royalty and noblemen. Patrick's family lives on Vancouver Island in a house "half stone, half stuccoand-timber [...] built in the Tudor style, and others" (102). The indecisiveness (half and half) and cumulative effect of style (Tudor, and others) suggests colonial mimicry, a mix both of social pretension and subservience to imported styles. In Ontario, "the college buildings were not old at all, but they were built to look old. They were built of stone. The Arts building had a tower, and the Library had casement windows, which might have been designed for shooting arrows through" (89). Buildings of prestige, be they family mansions or educational institutions, are meant to display their ties with the colonial heritage in a way that, if taken literally, sometimes seems absurd - in modern times there is no need to shoot arrows from the window of a library. But in Patrick's value system, his asserted taste for these objects and designs is a marker of social class, in the sense developed by Pierre Bourdieu in Distinction, whereby "upper-class propriety [...] treats taste as one of the surest signs of true nobility and cannot conceive of referring taste to anything other than itself" (11), while denying the social factor in the definition of taste. But Patrick's sense of taste undergoes a change over the course of the story.

\section{“Patrick did not mind Modern Art any more" (155)}

The colonial culture that Patrick embodies as a young man is perceived critically by Rose, both socially and intellectually. That culture is also challenged collectively by the development of modernism, to a certain extent. The dominant version of modernism is usually considered to span the period between 1890 and 1940 (Williams, "Modernism" 32). But in Canada, as in several other colonies, modernism, like other cultural moments, did not have the same impact as it did in the Western cultural centres of the time. As Glenn Willmott explains in his study on modernity in the Canadian novel, romance, realism, and modernism, which are three major moments of cultural development, had particular consequences in the Canadian context:

[T] he new romance will register the primacy of the (contingent) event over the (cosmogenetic) world, rather than the other way around. By the same proposition, realism too is turned inside out. The conventional function of realism, to register the interrelations and values of a given, secular world, or "what is," is eroded by the uneven and unstable, slash-and-burn transvaluations of a material life subject to the unpredictable synapses of global economy, media, and mobility. [...] [T] he break that marks modernism as a transnational artistic practice is not immediately visible in Canada as a break toward a new genre (hence new market), but rather as a break within - an exhaustion and turning inside out, as I suggest above - existing Canadian nineteenthcentury genres (and markets), toward another kind of practice that is self-fractured, radically incomplete, and experimental in the best modernist tradition. $(5,6)$

The third of the three dialectic processes which Willmott mentions here, between Canadian colonial culture and the abstraction of modern art, is an important motif in 
Canadian literature. It is at the core of Jane Urquhart's novel The Underpainter. Austin Fraser, an American abstract painter, recalls his friendship with George Kearns, a Canadian painter on ceramics whose craft Fraser considers sentimental, and does not see as real art. Through this relationship Urquhart examines two different approaches to culture in the period of the Second World War, when modernism took the form of abstraction in the United States, but did not have a comparable impact in Canada. Kerns's taste for ceramic painting embodies a culture that both sees itself as inscribed in an inherited tradition, and that values everyday decorated objects as a form of popular culture, rather than an abstract art that is willingly intellectual and detached from other human activities. Willmott, in his analysis of modernism in Canada, accounts for this kind of situation as follows:

In a society in which the onset and pace of modernization have been felt across a widely dispersed population and in relatively recent urban centres, and in a society which lacks the high culture of an aristocratic elite identified with the land and its history - in such a society, the institutions of popular culture may well be felt to be the most appropriate media of a new, collective, and artistic self-reflection. This is what happened in Canada. (8)

This is also what happens in $W h o$, where what is officially acknowledged as art never dominates, never quite offers a satisfying aesthetic media. Katherine Mansfield's story "The Garden Party," which teenage Rose reads at school, is full of compassion for poor people, but Mansfield herself, a colonial modernist writer, does not come through as having had an experience of poverty, her rendering of it being too poetic, too pretty for Rose. When Rose is a student, she boards with Dr. Heneshaw, a left-wing intellectual and activist. In her "small and perfect" house (82), fine objects are displayed, papers and magazines are there to be read. But Rose does not feel entirely comfortable there. To the books by Canadian modernist writers like Frank Scott or Dorothy Livesay Dr. Heneshaw suggests she should read, Rose prefers Thomas Mann or Tolstoy, a preference that lasts for several years, for she is reading Gide in the maternity ward after Anna's birth - "At that time she read only great writers" (183). Through her readings of foreign writers she reveals her need to open herself to the world and her unwillingness to identify with a more narrowly defined national literature. But she also can't help thinking back to Flo's house: “What Dr. Henshawe's house and Flo's house did best, in Rose's opinion, was discredit each other." (83) Dr. Henshawe's house is the epitome of fine taste but also the sign of an accumulation of cultural capital, to use Bourdieu's phrase ("Cultural Reproduction" 56), with the Chinese vases, rugs, and screens inherited from her missionary parents, the "photographs of Greek skies and ruins" in Rose's room taken by Dr. Heneshaw on a Mediterranean trip (99) attesting to a thorough education. By contrast, the bad taste of Flo's house, with its cheap decoration of neon lights and plastic curtains imitating lace, is a constant reminder to Rose of what poverty really means, not only materially but also aesthetically and intellectually. At the time Rose is angry at this, but in middle age, she reconsiders and appreciates Flo's interior decoration for the way it captures the story of her life. In $W$ ho popular culture is not only about heritage but also about people's actual material lives in their down-to-earth everydayness.

Rose appears, in the 1950s, as a young woman who feels oppressed by colonial culture (as represented by Patrick) and its many prejudices. In the 1960s and 70s, when she reaches middle age, she is free to welcome cultural change, including that of the sexual revolution, and has a career as an actress, after having been a radio host. However, 
throughout that period, there is palpable resistance in her immediate environment to these changes. Patrick, as a student, was relatively open to art: he took Rose to concerts and plays, to the Chinese temple room in the Toronto Museum. But after he started to work, his opinions changed and became rigid: "Modern Art was a Hoax. Avant-garde plays were filthy" (129). Things changed again with his second marriage to an artistically inclined woman (yet far wealthier than he), who, Rose finds out, "had made a dazzling living room with mirrors and pale velvet and a wire sculpture like blasted bird cages. Patrick did not mind Modern Art any more" (155). So Patrick's tastes evolve, but unlike Rose, he never jeopardises his social status in the process. As a young bridegroom, he knows it is time to join the family business and stop being a rebel student of history, and by the 1970s, he knows it is time to let go of his conservative opinions on art. Rose's brother Brian has even more conservative views, having no use for "[a]ctors, artists, journalists, rich people (he would never admit to being one himself), the entire Arts faculty of universities" (223).

The variety of ways in which the revolution of Modernism is received in Canadian society, going by the sample given above, illustrates the "break within," "the exhaustion and turning inside out" described by Willmott. There is no visible consensus on a national culture, and this lack of consensus is not simply class-bound. There is confusion, and some sort of fusion, as when Rose goes back to Hanratty and takes in the structural and cultural changes that have taken place there: whereas in the past " $t]$ here was Hanratty and West Hanratty, with the river flowing between them" (5), now "[t]he change from Hanratty to West Hanratty was hardly noticeable" (219). What used to be socially structuring borders seem to have vanished. The same goes for social groups: in the days when Rose was newly married, "the barriers between people were still strong and reliable; between arty people and business people; between men and women" (122). By the 1970s, at a party given to celebrate a professional award Rose has won, Flo finds herself amidst a "gathering of the bearded and beaded, the unisexual and the unashamedly un-Anglo-Saxon" (232). The paronomasia ("the bearded and beaded") referring to the hippies of the counterculture and their presence in the arts, the prefix "uni-" that denotes simultaneously an absence of strong gender types and a merging of the sexes, with the two privative prefixes that erase standard racial identification and hierarchy, signalling the presence of non-European types, as well as the absence of the expected deferential behaviour of the non-European, all signal the profound changes that have started transforming Canadian society, at any rate in Rose's milieu. The society depicted here seems to be one in transition (Regan 124), or perhaps it is one which lacks a transition, and undergoes rapid, confusing changes. These changes are subsumed into a dream Rose has after visiting the Home Flo now lives in, and in which she envisions

enormous wicker birdcages, Victorian birdcages, fancifully shaped and decorated. [...]

Then in one of the cages Rose spotted Flo, who was handsomely seated on a thronelike chair, spelling out words in a clear authoritative voice [...] and looking pleased with herself, for showing powers she had kept secret till now. $(228,229)$

The "wire sculpture like blasted bird cages" that Rose saw in Patrick's new house is transformed into a more elaborate, baroque-like version of the original Victorian birdcages which probably inspired the sculpture in the first place, while Flo is presented as being a prisoner of her situation, but is also in the regal position of the one who commands the spelling of words, a master of the logos, of language, which binds people. 
The kind of popular culture she embodies thus occupies an ambiguous position of privilege, as everything is turned upside down and inside out.

\section{Alternative Cultural Standards}

In 1974, Robert Kroetsch notoriously opened his introduction to a "Canadian issue" of Boundary 2 by stating that

Canadian culture evolved directly from Victorian into Postmodern. [...] The country that invented Marshall McLuhan and Northrop Frye did so by not ever being Modern. [...] The Canadian writer must uninvent the word. He must destroy the homonymous American and English languages that keep him from hearing his own tongue. (1) ${ }^{5}$

Rose as a young student and bride is fully exposed to the values of English culture and language - when Patrick asks her who administers her father's estate, she "thought an estate was land, such as people owned in England" (84-5). When she becomes friends with Jocelyn and Clifford, a young mother like her and her violinist husband, both American, she is also exposed to a different, Bohemian kind of culture. When Jocelyn reads "Howl" to her on the phone, from Allen Ginsberg's 1957 controversial poetry collection, she does not dare pronounce the word fuck in the poem; years later, that word has become part of Jocelyn and Clifford's language. Yet, when Rose is insulted by a former student of hers who uses that same word, her future friend Simon comments ironically: "Ah, the sensitive youth of our time! Their grace of language, their depth of feeling! We must bow before them" (194). This seems to indicate that there is more of a reserve towards language among Rose's peers than there is in the permissive American counterculture. These subtle differences between Rose and Jocelyn can be felt in their jokes.

Years after Patrick and Rose have divorced, Rose wonders what Patrick's new wife has done with the Wedgwood vases. Jocelyn gives the wisecrack a new twist when suggesting: "Maybe she has a campy laundry room. She keeps the bleach in one and the detergent in the other." To which Rose adds: "They sit perfectly symmetrically on the shelf" (156). Jocelyn's reference to camp is revealing. Camp is associated with what is "ostentatious, exaggerated, affected, theatrical; effeminate, homosexual" (Shorter Oxford English Dictionary). The vases, which to Patrick were valuable as aesthetic, artistic objects, presumably epitomizing truth, beauty, seriousness, become objects of derision in Rose and Jocelyn's facetious imagination: they become practical containers, in a process of detachment from Patrick and Rose's marriage, but they are still seen as valuable, and still earn some sympathy from their current owners.

In her analysis of camp, Susan Sontag remarks that it "is the farthest extension, in sensibility, of the metaphor of life as theatre" (280). So Patrick's life is turned into some kind of comedy by Jocelyn. This is in keeping with the whole theme of theatricality which underlies the book, starting with the "royal beatings" of the opening story, continuing with Flo's stories of Hanratty characters, and concluding with Rose's later career as an actress. ${ }^{6}$ The role Patrick attributes himself when projecting his story with Rose onto Edward Burne-Jones's King Cophetua and the Beggar Maid, a painting that

5. This statement has since then been challenged in the recent wave of criticism that reexamines modernism, for instance with projects aiming "to read the marginality of Canada's modernisms [and] generate counternarratives that contest the canonical narratives of both national and international modernisms" (Irvine 9).

6. On theatricality in $W h o$, see Sturgess and Murray and Garner. 
was inspired by a poem by Tennyson, makes Rose sceptical, but Patrick takes this role seriously: "He had many chivalric notions, which he pretended to mock [...]. The pretended irony would not fool anybody; it was clear that he did wish to operate in a world of knights and ladies; outrages; devotions." (91) ${ }^{7}$ With hindsight, this relation between the two of them can only appear as clichéd, caricatural, inherited from another time and place. Concerning the 19th century aestheticism of Burnes-Jones, Tennyson and others, Sontag observes that "[c]amp responds particularly to the markedly attenuated and to the strongly exaggerated" [...] such as "the swooning, slim, sinuous figures of pre-Raphaelite painting and poetry" (279). Early on, Patrick's aesthetics are bound to be turned into a subject of mockery - which Rose does at the time when suggesting he court Dr. Henshawe instead of herself.

Yet, Rose does not dismiss Patrick entirely, she does not turn against him: "Just the same, I like Patrick" (156), she tells Jocelyn. When mocking Patrick and his tastes, she does not condemn him totally. Sontag comments on the limits of the kind of aesthetic shift that camp performs:

Camp doesn't reverse things. It doesn't argue that the good is bad, or the bad is good. What it does is to offer for art (and life) a different - a supplementary — set of standards $[\ldots]$ : artifice as an ideal, theatricality. [...] Camp proposes a comic vision of the world. [...] The experiences of Camp are based on the great discovery that the sensibility of high culture has no monopoly upon refinement. Camp asserts that good taste is not simply good taste; that there exists, indeed, a good taste of bad taste. $(286,288,291)$

Camp, theatricality, the "good taste of bad taste," all offer Rose alternatives later on in her life. When Patrick goes to Hanratty for the first time, she is embarrassed by the plastic tablecloth, the tube of fluorescent light, the plastic swan holding coloured paper napkins. The aesthetic bad taste which reveals lack of education and poverty is mortifying for Rose. But "[y]ears later she would learn how to use it, she would be able to amuse or intimidate right-thinking people at dinner parties with glimpses of her early home" (108-9). Theatricality is her way out of embarrassment, a close solution to the supplement offered by camp. But later still, she is more reflective and understanding of people's backgrounds and stories. When going back to Flo's house, as Flo needs care, she looks around and wonders: "What were the things Flo put up to look at, in her little porch, where she had been sitting for years now with her joints and arteries hardening?" (219) The objects collected here, like a cabinet of curiosities, have no commercial value to anyone else than Flo; they are either personal or free gifts that are linked to loved ones or significant public events, records of personal and collective history, of Flo's life. As such, they have meaning which Rose takes the time to ponder on. Here, Rose's interpretation is not camp or ironical; there is no comic effect, no theatricality, but simply a consideration of Flo's life, an understanding of her loneliness in old age, and of her taking stock, as Rose herself has probably started doing.

Who Do You Think You Are? is arguably Munro's most postmodern book; it reflects on a Canadian form of postmodernism in culture, wherein borders, between social groups, cultural forms, ways of life, are receding. And it uses some of the strategies of postmodern writing to explore this: to quote Linda Hutcheon, "the postmodern uses its tendency towards self-reference as a way both of engaging with its own past, usually

7. For a detailed analysis of the role of the painting in the narrative, see Ventura. 
through irony and parody, and also of engaging with its audience" (xi). By the end of the book, middle-aged Rose feels simultaneously like an insider and outsider to her own milieu, and the lines that distinguish styles and genres are blurred in a way that echoes what Fredric Jameson calls a postmodern hyperspace, with "the strange feeling of an absence of inside and outside" (117). By contrast, in Munro's later stories, this reflection on art, or representation, or story-telling, and life, is done more reflectively, with a focus on the individual, rather than collective process of perception of the past.

\author{
Christine LORRE-JOHNSTON \\ University Sorbonne Nouvelle - Paris 3
}

\title{
Works Cited
}

Bourdieu, Pierre. "Cultural Reproduction and Social Reproduction." Knowledge, Education and Cultural Change: Papers in the Sociology of Education. Ed. Richard K. Brown. London: Tavistock, 1973. 56-68.

-. La Distinction, critique sociale du jugement. Paris: Minuit, 1979. Distinction: A Social Critique of the Judgement of Taste. Transl. Richard Nice. London: Routledge, 1984.

Briggs, Asa. Victorian Things. London: Penguin, 1988.

HiLl, Christopher. The Penguin Economic History of Britain, volume 2: 1530-1780. Reformation to Industrial Revolution. 1967. London: Penguin, 1992.

Hoy, Helen. "Rose and Janet: Alice Munro’s Metafiction.” Canadian Literature 121 (Summer 1989): 59-83.

Hutcheon, Linda. The Canadian Postmodern: A Study of Contemporary English-Canadian Fiction. Toronto: Oxford UP, 1988.

Irvine, Dean, ed. The Canadian Modernists Meet: Modernism, Antimodernism and Modernity. Ottawa: Ottawa UP, 2005.

Jameson, Fredric. Postmodernism, or, The Cultural Logic of Late Capitalism. Durham: Duke UP, 1991.

Kroetsch, Robert. "A Canadian Issue." boundary 23.1 (Autumn 1974): 1-2.

Laurence, Margaret. A Bird in the House. Toronto: McClelland and Stewart, 1963.

Lynch, Gerald. "No Honey, I'm Home': Place over Love in Alice Munro's Who Do You Think You Are?" The One and Many: English Canadian Short Story Cycles. Toronto: Toronto UP, 2001. 159-81. First published in Canadian Literature 160 (Spring 1999): 73-98.

Martin, Walter Rintoul. Alice Munro: Paradox and Parallel. Edmonton: U of Alberta P, 1987.

Mathews, Lawrence. “'Who Do You Think You Are?: Alice Munro's Art of Disarrangement." Probable Fictions: Alice Munro's Narrative Acts. Ed. Louis MacKendrick. Downsview: ECW, 1983. 181-93.

McCaIG, JoAnn. Reading in Alice Munro's Archives. Waterloo: Wilfrid Laurier UP, 2002.

Munro, Alice. Who Do You Think You Are? 1978. Toronto: Penguin, 1996.

-. Runaway. New York: Alfred Knopf, 2004.

Murray, Jennifer, and Lee Garner. "From Participant to Observer: Theatricality and Distantiation in Alice Munro's 'Lives of Girls and Women' and 'Royal Beatings'.' Journal of the Short Story in English / Les Cabiers de la nouvelle 51 (Autumn 2008): 149-58.

Noonan, Gerald. "Alice Munro's Short Stories and the Art That Distrusts Art." Short Fiction in the New Literatures in English. Ed. Jacqueline Bardolph. Nice: Faculté des Lettres et Sciences Humaines, 1989. 141-6.

Regan, Stephen. "'The Presence of the Past': Modernism and Postmodernism in Canadian Short Fiction." Narrative Strategies in Canadian Literature. Ed. Coral Ann Howells and Lynette Hunter. Milton Keynes, Philadelphia: Open UP, 1991. 108-39.

SONTAG, Susan. "Notes on Camp." Against Interpretation and Other Essays. New York: Farrar, Straus and Giroux, 1966.

Struthers, J. R. (Tim). “The Real Material: An Interview with Alice Munro.” Probable Fictions: Alice Munro's Narrative Acts. Ed. Louis MacKendrick. Downsview: ECW, 1983. 5-36.

STURGESS, Charlotte. "La représentation féminine et la mise en scène dans The Beggar Maid: Stories of Flo and Rose d'Alice Munro." Commonwealth 17.2 (Spring 1995): 44-9.

URQUHART, Jane. The Underpainter. Toronto: McClelland and Stewart, 1997.

-. A Map of Glass. London: Bloomsbury, 2005.

Ventura, Héliane. "De l'image au texte : le devenir-nouvelle de 'The Beggar Maid' d'Alice Munro." Études anglaises 61.1 (2008): 58-67. 
Williams, Raymond. "Culture." Keywords: A Vocabulary of Culture and Society. 1977. London: Fontana, 1983 ( $2^{\text {nd }}$ ed.). 87-93.

—. "When Was Modernism?" The Politics of Modernism: Against the New Conformists. London: Verso, 1989. 31-5.

Willmott, Glenn. Unreal Country: Modernity in the Canadian Novel in English. Kingston, Montreal: McGill-Queen's UP, 2002. 